\title{
REGIONAL GEOLGICAL MAPPING IN TROPICAL ENVIRONMENTS USING LANDSAT TM AND SRTM REMOTE SENSING DATA
}

\author{
Amin Beiranvand Pour*, Mazlan Hashim \\ Geoscience and Digital Earth Centre (Geo-DEC) \\ Research Institute for Sustainability and Environment (RISE) \\ Universiti Teknologi Malaysia (UTM) \\ 81310 UTM Skudai, Johor Bahru, Malaysia \\ *Corresponding author: a.beiranvand@utm.my
}

\section{Commission VI, WG VI/4}

\begin{abstract}
KEY WORDS: Landsat Thematic Mapper (TM); Shuttle Radar Topography Mission (SRTM); Regional geology mapping; Tropical
\end{abstract} environments

\begin{abstract}
:
Landsat Thematic Mapper (TM) and Shuttle Radar Topography Mission (SRTM) data were used to produce geological maps in tropical environments. Lineament, lithology and landform maps were produced for all states in peninsular Malaysia in this study. Kedah, Perak and Terengganu states have been selected as case studies to demonstrate the results of the data and techniques used. Directional filtering technique was applied to Landsat TM bands 4, 5 and 3 for lineament mapping. The lithology map was produced using Landsat TM bands combination consist of bands 4, 3 and 2. Digital elevation model and landform map were produced using SRTM data in 3 Dimension (3D) and 2 Dimension (2D) perspective views, respectively. The produced geological maps and the remote sensing data and methods applied in this study are mostly appropriate for hazard risk mapping applications and mineral exploration projects in the peninsular Malaysia and tropical environments.
\end{abstract}

\section{INTRODUCTION}

Remote sensing data enable direct observation of land surfaces at repetitive intervals and therefore allow mapping of a large extent of the land surfaces. Geological mapping involves the identification of landforms, types of rock and also the structure of rocks (folds, faults and fractures). All these geological units and structures are then portrayed on maps in their correct spatial relationship with one another. Remote sensing data provides many advantages for improving the regional geological mapping process (Hashim et al., 2013; Pour and Hashim 2014, 2015). However, because most of the geological features are entirely or partly hidden beneath the earth's surface, information of most geological cannot be directly recorded by remote sensing. Thus interpretation of satellite images for geological mapping is normally based on the indirect evidence that can be visible at the surface. The distribution of vegetation can often be used as an indirect indicator of the composition of the underlying rock material in tropical environments.

Landsat Thematic Mapper (TM) with seven spectral bands has been used for regional scales of geological mapping. Numerous investigators have used Landsat false color composite images to identify geomorphological expres $\neg$ sions and regional structural features (Raharimahefa, and Kusky, 2007, 2009; Hashim et al., 2013; Pour et al., 2013.) The Shuttle Radar Topography Mission (SRTM) data have been used for many applications of digital elevation data, including geomorphology, hydrology, forest ecology, glaciology and volcanology (Frey and Paul, 2012; Pan et al., 2013).
The SRTM data are unique in the vast majority of the Earth's surface been mapped with a single consistent method in such a short period of time. This has resulted in an unprecedented topographic snapshot, giving way to a vast range of novel applications in the geosciences. SRTM data have been particularly useful for areas where previously limited topographic data were available (Zandbern, 2008). The SRTM employed two synthetic aperture radars, a C-band system (5.6 $\mathrm{cm})$ and an X-band system $(3.1 \mathrm{~cm})$. X radar was included as an experimental demonstration to be used as an independent dataset to help resolve problems in C radar processing and quality control (Rosen et al., 2001). Intermediate textural variation of outcrop and surface roughness, including faults, folds, topographic breaks, bedding, depressions, lithologies and intrusive contacts can be detected using C-band radar images (Spatz, 1997).

In this paper, the applicability of automated derivation of geological lineaments, surface lithology and geomorphology information from the Landsat TM and SRTM remote sensing data sets was investigated. Moreover, remote sensing driven geological maps are useful for geological hazards management and mineral exploration in peninsular Malaysia. 


\section{MATERIALS AND METHODS}

\subsection{Satellite data}

The Landsat TM image was obtained from the U.S. Geological Survey's Earth Resources Observation System (EROS) Data Center (EDC). Thirty one level 1B scenes were acquired during August 2001 to March 2003 with low cloud cover for the whole of the Peninsular Malaysia. The SRTM 90m DEM's have a resolution of $90 \mathrm{~m}$ at the equator, and are downloaded in $\begin{array}{lllll}\text { mosaicked } & 50 & \mathrm{X} & 50 & \text { tiles }\end{array}$ (ftp://e0srp01u.ecs.nasa.gov/srtm/version2/SRTM3/). All are produced from a seamless dataset to allow easy mosaicing. We downloaded the tiles in GeoTiff format to facilitate their ease to produce seamless mosaic for Peninsular Malaysia. The Landsat TM and SRTM data sets of the Peninsular Malaysia were processed using the ArcInfo GIS software and ERDAS IMAGINE software packages; where geocoded both to the common local mapping coordinate system.

\subsection{Image processing techniques}

Typical pre-processing corrections carried out included both (i) radiometric correction to minimise effects of atmospheric, and (ii) geometric correction to rectify image geometric distortions due to motion of the sensor while orbiting the earth and other effects. These processes are essential to enable the image to represent the real world (Jensen, 2005). All these images were then further enhanced to improve the visual interpretability of an image and to enable the identification and recognition of various geological structures.

\subsubsection{Data processing}

In the lineament mapping, the pre-processed Landsat TM bands 4,5 and 3 were used. The spatial features of the lineaments inherent in the image are first enhanced by applying nondirectional edge filtering technique for each band. Nondirectional filters enhance linear features having almost any orientation in an image. The exception applies to linear features oriented parallel with the direction of filter movement; these features are not enhanced (Haralick et al., 1987). Directional filters were applied to the image for detailed identification of linear features. Directional filter is a first derivative edge enhancement filter that selectively enhances image features having specific direction components (gradients). It can be used in geological applications to highlight faults and lineaments. Directional filters were used to enhance specific linear trends in the image (Figure 1). Four principal Directional filters: N-S, EW, NE-SW, and NW-SE with a 7*7 kernel size were applied. 7*7 kernel matrix was selected to enhance semi-smooth and smooth/rough features (Jensen, 2005). The detected lineaments were later compared to the corresponding ancillary data.

The surface lithology was derived using Landsat TM bands 4, 3 and 2. Other band combinations have also been examined (432, $452,457,523,754$ and 753 ), but band 4-3-2 was found to be the best. In band combination of 4-3-2 the displaying images appear reddish in colour. Red-Green-Blue (RGB) colourcomposite was used for selected bands to provide visual interpretation of geological lithology in the study area. This band combination was spatially enhanced for deriving the textures, which can be associated with lithologic information. The lithology types such as igneous, Quaternary deposit and sedimentary rock were classified accordingly based on the differences in tones, which were respectively dark, intermediate and bright. The surface lithology can be traced using interpretative elements of shape, size, pattern, and surrounding tones.

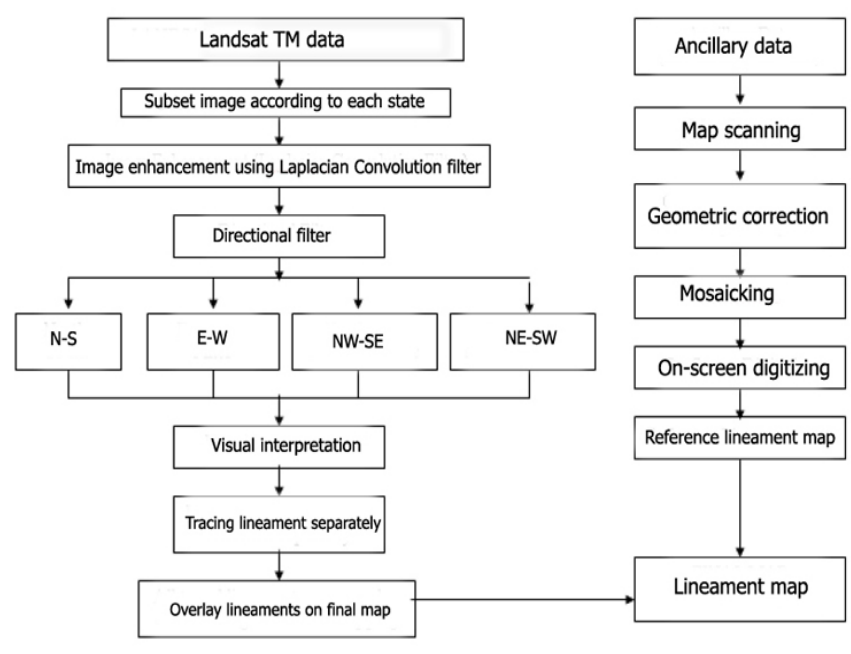

Figure 1. Methodology used to extract lineaments.

SRTM images were used to extract geomorphological information in this study. Geomorphology were derived in two ways, namely: (i) the 2D perspective of landforms with elevation classes, (ii) the $3 \mathrm{D}$ perspective view of the landforms, which contained an elevation model with layers of information draped over it. In order to extract geological information from the images, other ancillary data such as topographic, lithology and lineaments map were used as references.

On-screen digitizing was performed in order to generate vector layers of information based on the digital topographic maps of Peninsular Malaysia. Selected geomorphologic features were digitized using the ESRI ArcView vector creation tools from the topographic maps. The selected features were rivers, lakes and dams which were classified as water bodies. The vector features were digitized as polygons and stored as a shapefile (.shp). Landsat ETM mosaic images of Malaysia were subset into states and displayed in the 7,5, and 2 combinations to produce a natural-like view. The images were subjected to brightness/contrast enhancement to produce good looking images for display.

The DEM was displayed in the Virtual GIS Viewer in ERDAS Imagine. The scene properties were adjusted to create a suitable view before the Landsat ETM image was overlaid on the DEM to create a 3D perspective of landforms. The vector (digitized) geomorphologic features were overlaid on top of the raster images to produce the final 3D perspective. The DEM was classified into three elevation classes. The DEM was split into below $150 \mathrm{~m}, 150 \mathrm{~m}$ to $300 \mathrm{~m}$ and above $300 \mathrm{~m}$. The splitting of the DEM was performed using ERDAS Modeler model. The elevation classes were vectorised to create vector polygons. The Elevation classes and the geomorphologic features were overlaid in ArcGIS to create the 2D perspective of landforms. The vector features in the form of polygons were colour coded to display the various classes of elevation and water bodies. 


\section{RESULTS}

The geological maps, including lineament, lithology and landform for all states in Malaysia were produced from the image processing techniques implemented to Landsat TM images and SRTM data in this study. Peninsular Malaysia consists of 11 states (Johor, Kedah, Kelantan, Melaka, Negeri Sembilan, Pahang, Perak, Perils, Selangor, and Terengganu). In this study, we selected Kedah, Perak and Terengganu states to show the results of the techniques and produced geological maps.

Landsat TM image of Kedah displayed using combination of bands 4-5-3 and geological maps produced from the image. Figure 2 shows lineament map of Kedah. The dominant directions in Kedah are N-S, NW-SE and NE-SW. Kedah with 9,425 km2 comprises sedimentary/metamorphic rock, igneous rock and Quaternary deposit. Texture analysis of Landsat TM bands 4,3 and 2 with spatial filtering technique can enhance surface lithology. Display of this texture, produces reddish tone image. Dark, intermediate and bright red tones represent igneous, Quaternary deposit and sedimentary/metamorphic rocks, respectively. Figure 3 shows litology map of Kedah. The results derived from SRTM data for Kedah terrain indicated that approximately $70 \%$ are lowlands (less than $150 \mathrm{~m}$ ), whereas about $25 \%$ are uplands (higher than $300 \mathrm{~m}$ ). The remaining $5 \%$ is consisting of lands with elevation between $150 \mathrm{~m}$ and $300 \mathrm{~m}$ (Figure 4). There are two main river systems in Kedah, namely, Sungai and its tributaries and Sungai Merbok and its tributaries. Kedah has $89 \mathrm{~km}$ of coastline with clusters of many small islands in Straits of Melaka like Pulau Langkawi, Pulau Dayang Bunting and Pulau Tuba. The three main lakes in Kedah are Pedu lake, Muda lake and Dayang Bunting lake (Figure 4).

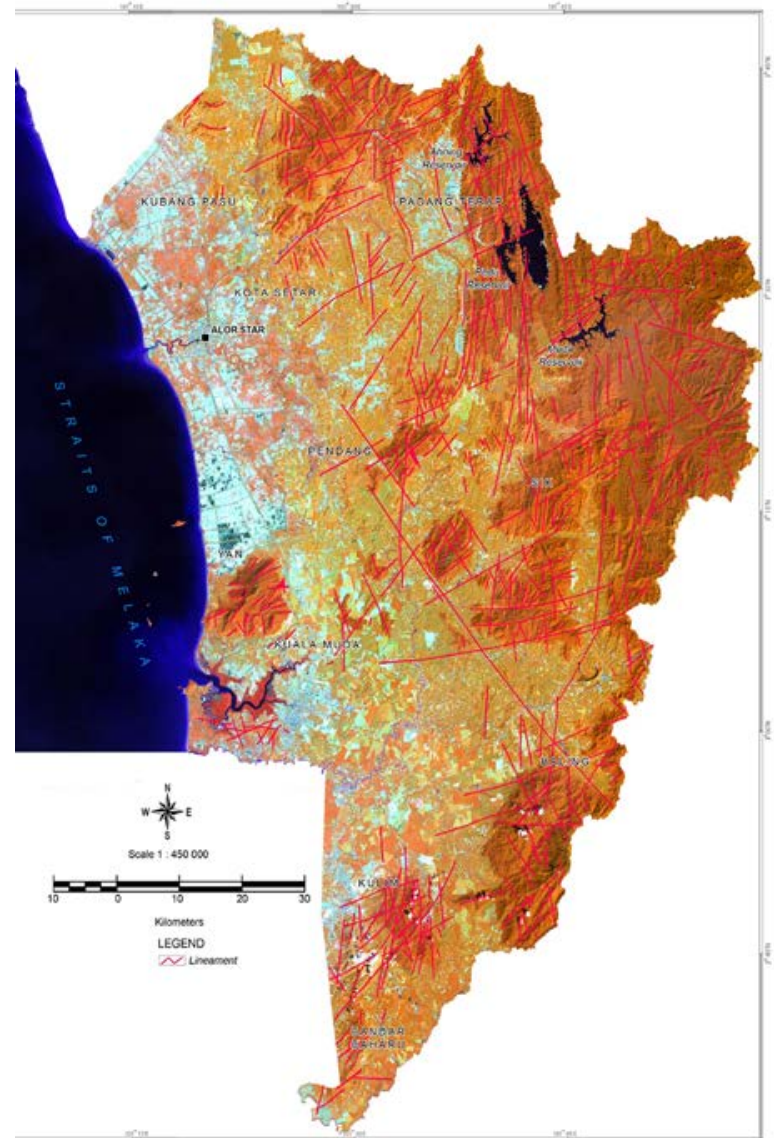

Figure 2. Lineament map of Kedah.

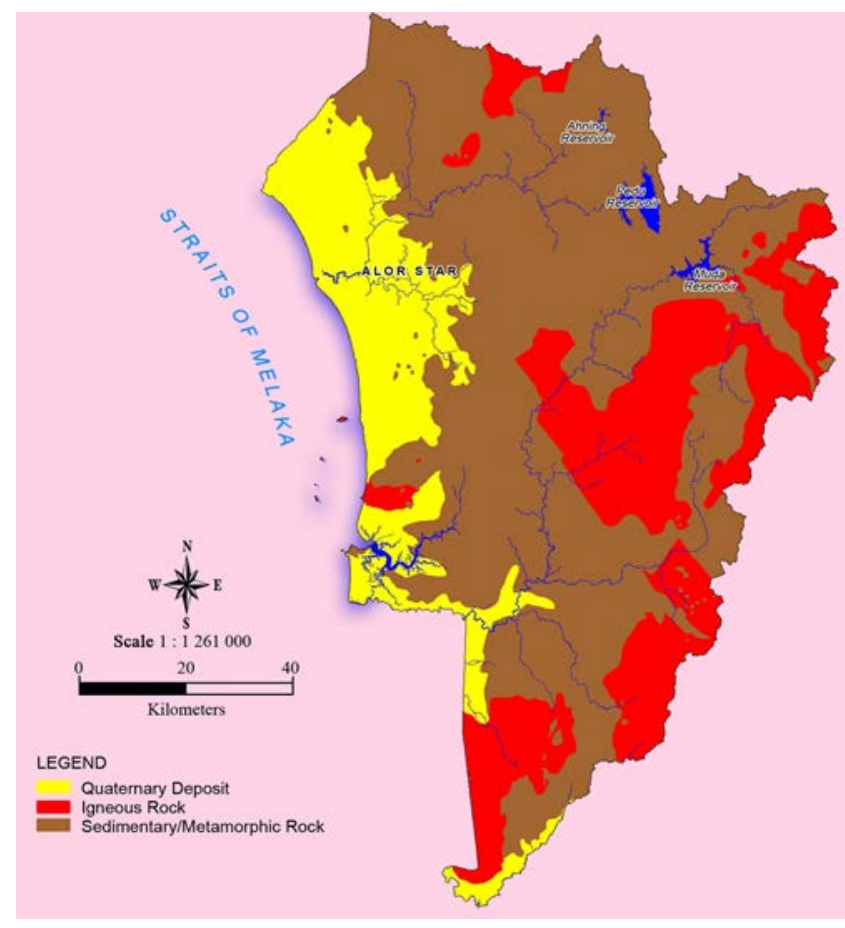

Figure 3. Litology map of Kedah.

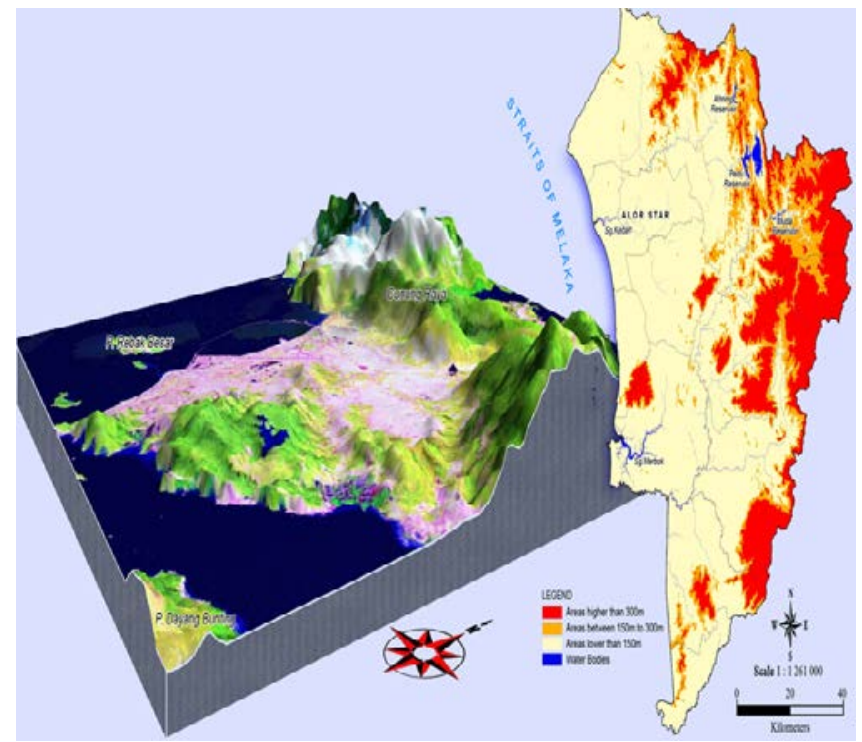

Figure 4. Landform map of Kedah.

Perak with an area of 20,952 km2 is situated in the west coast of the Peninsular Malaysia. Landsat TM image of Perak displayed using combination of bands 4-5-3 and geological maps derived from the image. The dominant directions in Perak are N-S, NWSE and NN-SW. Figure 5 illustrates lineament map of Perak. Texture analysis of Landsat TM bands 4, 3 and 2 with spatial filtering technique were produced lithology map for Perak (Figure 6). Igneous rocks are the most dominated rocks in Perak. The produced landform map for Perak (Figure 7) shows that approximately $50 \%$ of its terrain are uplands (higher than $300 \mathrm{~m}$ ) covering the southeast and north parts of Perak, whereas about $40 \%$ are lowlands (less than $150 \mathrm{~m}$ ). The remaining $10 \%$ is consisting of lands with elevation between $150 \mathrm{~m}$ to $300 \mathrm{~m}$. There are three main river system in Perak namely, Sungai 
Perak tributaries, Sungai Manjiung tributaries and Sungai Bernam tributaries in the southwest of Perak. Perak has $187 \mathrm{~km}$ of coastline with clusters of many small islands in the southwest of Perak, notably Pulau pangkor.

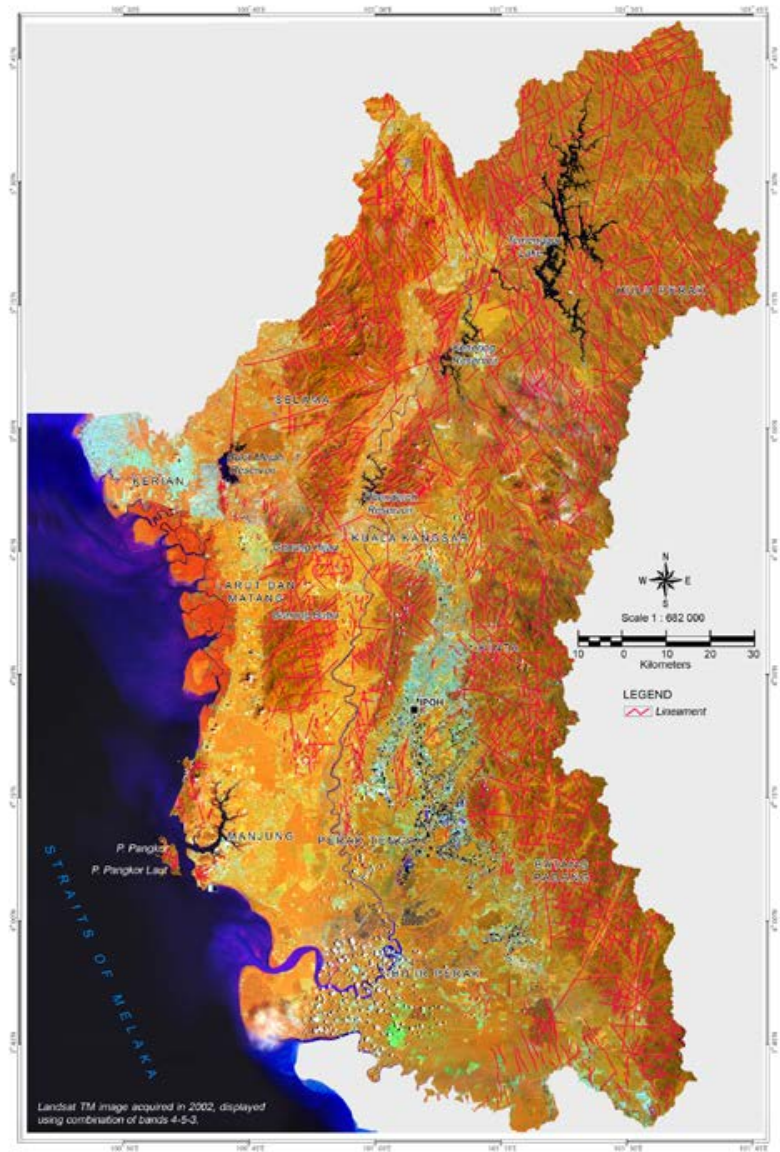

Figure 5. Lineament map of Perak.

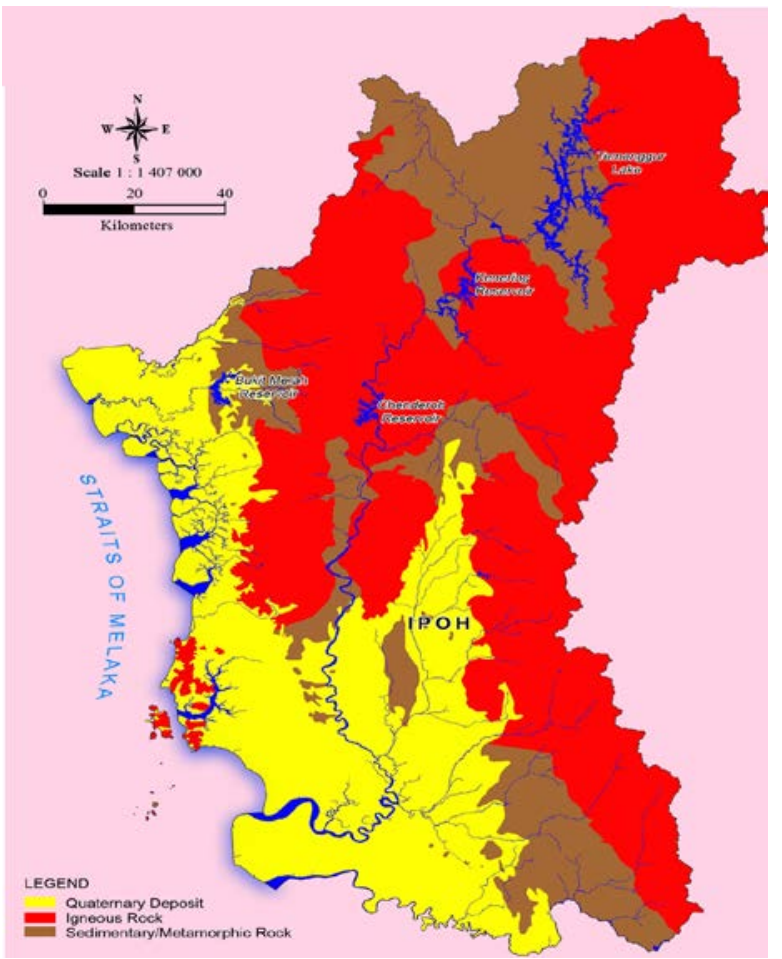

Figures 6. Litology map of Perak.

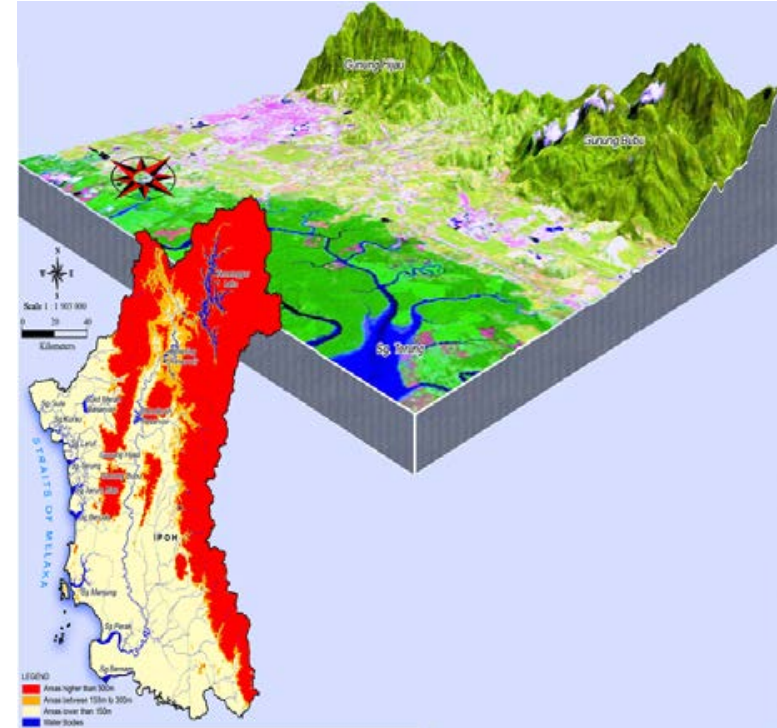

Figure 7. Landform map of Perak.

Terengganu with a 12,995 km2, comprises of igneous rocks, Quaternary deposit and sedimentary/metamorphic rocks is situated in the northeast of the Peninsular Malaysia. Lineament map shows that the dominant directions for ridge lineament in Terengganu are N-S and NW-SE (Figure 8). Lithology map was produced using spatial filtering technique on TM bands 4, 3 and 2 for Terengganu (Figure 9). Igneous and sedimentary/metamorphic rocks cover most parts of the ground in this region. Figure 10 shows landform map for Terengganu. Approximately $60 \%$ of Terengganu's terrain are lowland (less than $150 \mathrm{~m}$ ), whereas about $30 \%$ are uplands (higher than $300 \mathrm{~m})$. Lands with elevation between $150 \mathrm{~m}$ and $300 \mathrm{~m}$ cover $10 \%$ of this area (Figure 10). There are two main river systems in Terengganu, namely, Sungai Terengganu tributaries and Sungai Dungun tributaries. Terengganu has $230 \mathrm{~km}$ of coastline with clusters of many small islands in South China Sea like Pulau Redang, Pulau Kapas, Pulau Bidung Laut. The main lake in Terengganu is Kenyir Lake. Gunung Lawit is the highest point in this state (Figure 10).

Produced lineament maps using Landsat TM data for selected states were compared with the lineament maps produced by the Department of Minerals and Geoscience (GSM), it is found that most of the line matched to each other. Table 1 shows the number of lineament found on maps produced using Landsat TM data as compared to the number of lineament from maps produced by the Department of Minerals and Geoscience (GSM). Lithologic information extracted from Landsat images is almost similar with those found on maps produced by the Department of Geosains and Minerals (GSM). Area covered by various lithologic types found to be matched with each other. Table 2 shows the three major types of rocks identified in selected states. Lithologic information extracted from Landsat images is almost similar with those found on maps produced by the Department of Geosains and Minerals (GSM). 
Table 1: Total number of lineaments from Maps Produced by the Department of Mineral \& Geoscience (GSM) Ipoh and from Maps Produced Using Landsat TM Images.

\begin{tabular}{|l|l|c|c|c|c|}
\hline No & State & $\begin{array}{c}\text { Total No. of } \\
\text { Ridge } \\
\text { Lineament } \\
\text { (Dept of } \\
\text { GSM) }\end{array}$ & $\begin{array}{c}\text { Total Ridge } \\
\text { Lineament } \\
\text { (Landsat TM } \\
\text { images) }\end{array}$ & $\begin{array}{c}\text { Total } \\
\text { Fracture } \\
\text { Lineament } \\
\text { (Dept.of } \\
\text { GSM) }\end{array}$ & $\begin{array}{c}\text { Total } \\
\text { Fracture } \\
\text { Lineament } \\
\text { (Landsat TM } \\
\text { images) }\end{array}$ \\
\hline 1. & Kedah & 610 & 590 & 311 & 268 \\
\hline 2. & Terengganu & 524 & 464 & 623 & 524 \\
\hline 3. & Perak & 1221 & 830 & 1042 & 793 \\
\hline
\end{tabular}

Table 2. Percentages of area covered by types of lithology in Malaysia.

\begin{tabular}{|l|c|c|c|c|c|c|}
\hline \multirow{2}{*}{ STATE } & \multicolumn{3}{|c|}{ LITHOLOGY (\%) } & \multicolumn{3}{c|}{ LITHOLOGY (\%) EXTRACT FROM } \\
& \multicolumn{3}{|c|}{ IMAGE } \\
\cline { 2 - 7 } & Igneous & Quaternary & Sedimentary & Igneous & Quaternary & Sedimentary \\
\hline Kedah & 54 & 18 & 28 & 47 & 23 & 30 \\
\hline Terengganu & 60 & 31 & 18 & 55 & 27 & 18 \\
\hline Perak & 44 & 24 & 32 & 47 & 23 & 30 \\
\hline
\end{tabular}

\section{CONCLUSIONS}

This study indicates the capability of the remote sensing data to produce geological maps for tropical regions. Landsat TM and SRTM images were used for producing lineament map, lithology map and landform map of all states in Malaysia. Band combinations and directional filters were employed on Landsat TM data for lineament and lithology mapping. 2D and 3D perspective view of landforms were created using SRTM data. Lineament map is very useful for reconnaissance stages of epithermal gold and polymetallic vein-type ore exploration as well as hazard risk mapping. Gold mineralization in Malaysia is associated with structural features at both regional and district scales. Lithology map can also be helpful to identify potential areas of gold and polymetallic mineralization in igneous rocks, sedimentary and metamorphic rocks. Landform map is broadly applicable for catastrophic disasters such as flood hazard mapping, which is typical in tropical monsoon climatic features.

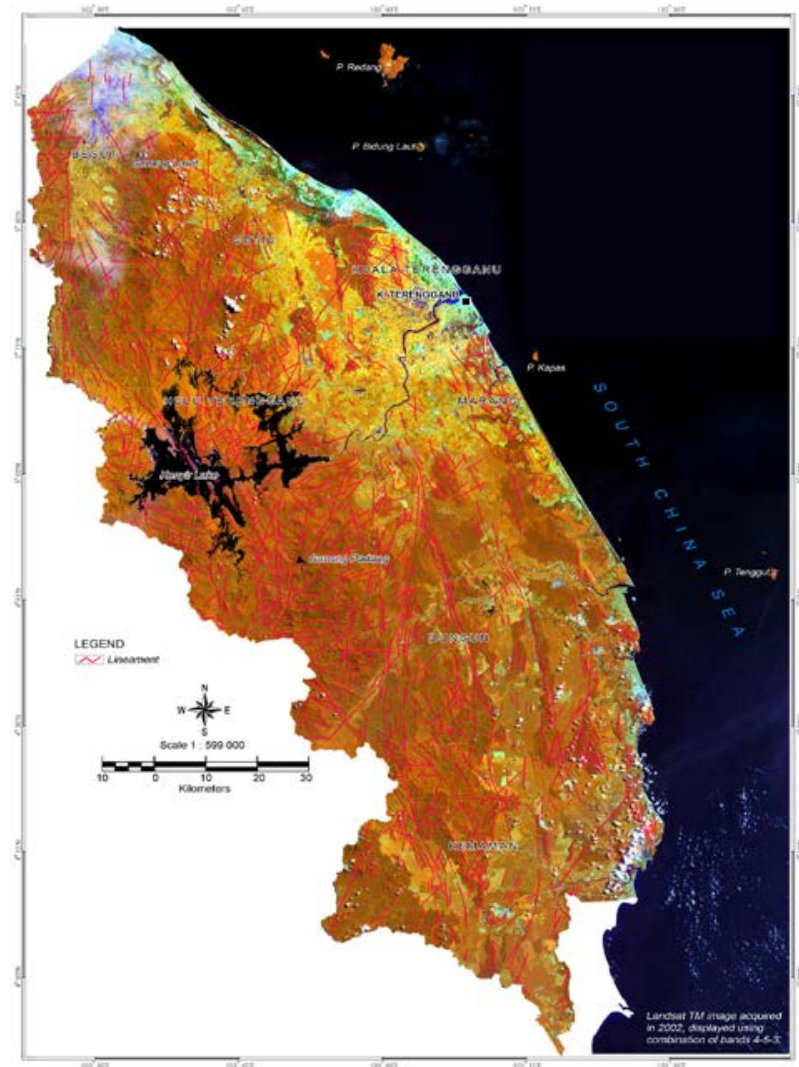

Figure 8. Lineament map of Terengganu.

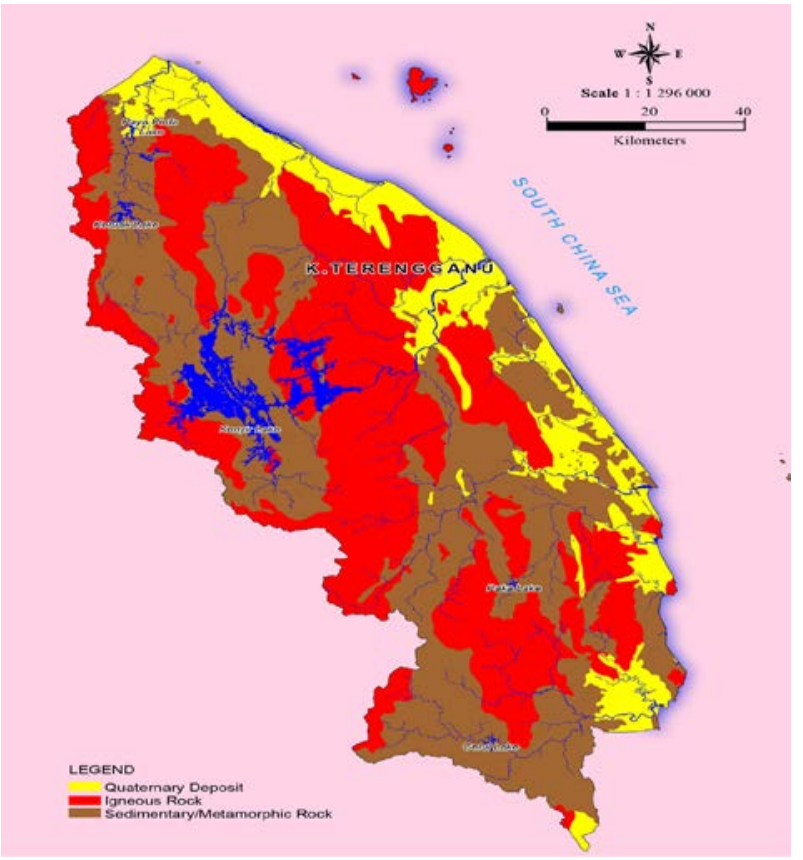

Figure 9. Litology map of Terengganu. 




Figure 10. Landform map of Terengganu.

\section{ACKNOWLEDGEMENTS}

This study was conducted as a part of TRGS grant (Vote no: R.J130000.7809.4L837), Ministry of Higher Education (MOHE) Malaysia. We are thankful to the Universiti Teknologi Malaysia for providing the facilities for this investigation.

\section{REFERENCES}

Frey, H., Paul, F., 2012. On the suitability of the SRTM DEM and ASTER GDEM for the compilation of topographic parameters in glacier inventories. International Journal of Applied Earth Observation and Geoinformation, 18, 480-490.

Haralick, R.M., Sternberg, R.S., Zhuang, X., 1987. Image Analysis Using Mathematical Morphology. IEEE Transactions on Pattern Analysis and Machine Intelligence, Vol. PAMI-9, No. 4, July 1987, pp. 532-550.

Hashim, M. S. Ahmad, M.A.M. Johari, A.B Pour., 2013. Automatic lineament extraction in a heavily vegetated region using Landsat Enhanced Thematic Mapper (ETM+) imagery, Adv. Space Research, vol.51, pp. 874-890.

Jensen, J.R., 2005. Introductory Digital Image Processing. Pearson Prentice Hall, Upper Saddle River.

Pan, F., Liao, J., Li, X., Guo, H., 2013. Application of the inundation area-lake level rating curves constructed from the SRTM DEM to retrieving lake levels from satellite measure dinundation areas. Computers \& Geosciences, 52, 168-176.

Pour, B.A., Hashim, M., Van Genderen, J., 2013. Detection of hydrothermal alteration zones in a tropical region using satellite remote sensing data: Bau goldfield, Sarawak, Malaysia. Ore Geology Reviews, 54, 181-196.

Pour, A.B., Hashim, M., 2014. Structural geology mapping using PALSAR data in the Bau gold mining district, Sarawak, Malaysia, Adv. Space Research, vol.54 (4), pp. 644-654.
Pour, A.B., Hashim, M., 2015 Structural mapping using PALSAR data in the Central Gold Belt Peninsular Malaysia, Ore Geology Reviews, vol.64, pp. 13-22.

Raharimahefa, T. T.M Kusky, 2007. Stuctural and remote sensing studies of the southern Betsimisaraka Suture, Madagascar, Gond. Research, vol.10, pp. 186-197.

Raharimahefa, T. T.M Kusky, 2009. Stuctural and remote sensing analysis of the southern Betsimisaraka Suture in northeastern Madagascar, Gond. Research, vol.15, pp. 14-27.

Rosen, P., Eineder, M., Rabus, B., Gurrola, E., Hensley, S., Knopfle, W., Breit, H., Roth, A. and Werner, M., 2001. SRTM Mission-Cross Comparison of X and C Band Data Properties. Proceedings of IGARSS, Sydney, Australia (21 Sep 2001).

Spatz, D.M., 1997. Remote sensing characteristics of the sediment- and volcanic-hosted precious metal systems: imagery selection for exploration and development. International Journal of Remote Sensing, 18 (7), 1413-1438.

Zandbergen, P., 2008. Applications of shuttle radar topography mission elevation data. Geography Compass, 2/5 1404-1431. 